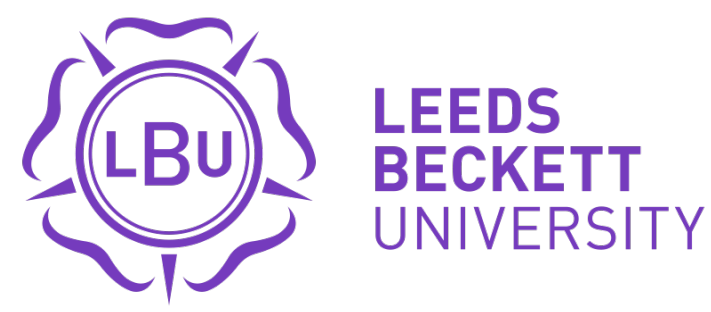

Citation:

Ogunnusi, M and Omotayo, T and Hamma-Adama, M and Awuzie, BO and Egbelakin, T (2021) Lessons learned from the impact of COVID-19 on the global construction industry. Journal of Engineering, Design and Technology. ISSN 1726-0531 DOI: https://doi.org/10.1108/jedt-05-2021-0286

Link to Leeds Beckett Repository record:

https://eprints.leedsbeckett.ac.uk/id/eprint/8045/

Document Version:

Article (Accepted Version)

Creative Commons: Attribution-Noncommercial 4.0

The aim of the Leeds Beckett Repository is to provide open access to our research, as required by funder policies and permitted by publishers and copyright law.

The Leeds Beckett repository holds a wide range of publications, each of which has been checked for copyright and the relevant embargo period has been applied by the Research Services team.

We operate on a standard take-down policy. If you are the author or publisher of an output and you would like it removed from the repository, please contact us and we will investigate on a case-by-case basis.

Each thesis in the repository has been cleared where necessary by the author for third party copyright. If you would like a thesis to be removed from the repository or believe there is an issue with copyright, please contact us on openaccess@leedsbeckett.ac.uk and we will investigate on a case-by-case basis. 


\title{
Lessons learned from the impact of COVID-19 on the global construction industry
}

\begin{abstract}
Purpose - The construction industry represents most of every country's savings and vital to continued economic growth and activities, especially in developing countries. The impact of the severe acute respiratory syndrome-2 disease (COVID -19) on the government's income resulted in the expectation of many public projects being cancelled or delayed providing little opportunity for the emergence of new public projects. This paper aims to collate a global qualitative perspective (survey interviews) on the lessons learned during the COVID19 pandemic and the positive and negative impacts for future-proofing the construction sector.
\end{abstract}

Design/Methodology - In total, seventy-six (76) respondents from 5 continents excluding South America responded to the online open-ended structured questionnaire. Data collected were analysed through Al analytics tool - Zoho analytics.

Findings - The themes indicating the positive impact obtained from the interview were overhead cost reduction, remote working environment, focus on health and safety, improved productivity and sustainability goals while the themes signifying the negative impact were low business turnover, delays in construction payment and output, difficulties working from home and job losses. Supply chain management, construction project management improvement, concentration on health and safety and effective virtual working environment were collated as themes on lessons learned.

Social implications - The major finding of this study emphasis on the need to improve the occupational health and safety and onsite safety measures for futureproofing of the construction industry.

Originality/value - The findings from the analyses made clear the imperativeness of the built environment research focusing on novel framework and strategies for future proofing the construction industry.

Keywords: Construction industry, Countries, COVID-19, epidemic

Paper type - Research paper

\subsection{Background of the study}

Stasiak-Betlejewska and Potkany (2015) considered the construction industry as a complex sector of the economy that encompasses a wide range of stakeholders and has broadranging connections with other extents of activity such as manufacturing and energy usage, finance, materials, equipment, and labour. This signifies that the construction industry represents most of every country's savings and vital to continued economic growth and activities, especially in developing countries (Rangelova, 2015; Oladirin, Ogunsemi and Aje, 2012). The impact of the severe acute respiratory syndrome-2 disease (COVID -19) on the government's income resulted in the expectation of many public projects being cancelled or delayed providing little opportunity for the emergence of new public projects (FinancialNigeria, 2020). This paper aims to collate a global qualitative perspective on the lessons learned during the COVID-19 pandemic and the positive and negative impacts for future-proofing the construction sector. 


\subsection{Literature}

\subsection{The future direction of the global construction industry for the post-COVID-19 era.}

Stride, Suresh and Renukappa (2020) relayed the immediate exceptional changes that COVID-19 has brought to many construction workplaces and companies. The pandemic has significantly changed work, communication and socialisation patterns associated with daily living. It has resulted in drastic changes within construction. Indications abound that productivity and regular (non- COVID-19 related) health and safety performance might have progressed as a result of these changes (Jones et al., 2020). Victor, Mmusi and Belinda (2020) described the COVID 19 pandemic as a universal societal shock that is distinctive in our lifetime. Many construction organsiations instituted business continuity capacities to meet the challenges of COVID-19 distruptions. Babu and Sudhakar (2016) affirmed that if a construction company appraises a crisis well and effectively implements crisis management strategies, they can undermine crises with minimal or zero damage.

\section{$\gg>$ Insert Figure $1<<<$}

Uchehara et al. (2020) undertook a review on the impacts of COVID-19 on the UK real estate supply chain. Uchehara et al. (2020) described how the UK construction projects suffered from delay, temporarily closed, and cancellations. Considering a similar investigation on the impacts of COVID-19 on the construction sector, Ogunnusi et al. (2020) empirical study revealed partial and complete stoppage of work generally aided by authorities that resulted in a complete disruption of the procurement process and the industry at large. Written evidence on the impact of the pandemic tendered by Stride, Suresh and Renukappa (2020) recommended $5 C^{\prime}$ 's - that is, create culture, control systems, courageous decisions, combat mental health and care for employees. In short, an investigation conducted in Los Angeles in the United States of America concluded that the construction workers were reporting the utmost number of positive cases of COVID 19 as compared to workers in other industries such as healthcare, transportation and manufacturing (Alsharef et al., 2021). The UK construction industry had to implement changes to be productive while adhering to the rules set for the lockdown (Stride, Suresh and Renukappa, 2020).

Long-term strategies need to be set to future proof the workplace, and the construction sector will need to be planned to develop industry 4.0 employee welfare and knowledge management (Stride, Suresh and Renukappa, 2020). Despite the unannounced advent of the pandemic created by COVID 19, the construction industry can categorically identify the positive and the negative impact in the industry as detailed below.

>> Insert Table $1<<<$

The contents of Table 1 were discussed along the lines of the positive and negative impact of COVID-19 on the construction industry.

\subsection{Positive impacts}

Ogunnusi et al., (2020), and Kshirsagar, Mansour and Metakis (2020) identified 'opportunity to improve on virtual alternatives' as a positive side of the COVID 19. Some staff in some contracting industries were offered relevant technology such as laptops and mobiles to continue working from home. Remote working has significantly saved a company per month paper printing from 35,000 sheets to 1000 sheets (Stride, Suresh and Renukappa, 2020). 
Identifying new opportunities created with the pandemic, Alsharef et al., (2021) noted new opportunities experienced in the construction industry to recruit skilled workers; demand in the transportation, medical and residential sectors; and lower interest rates. Industry 4.0 is set to proceed rapidly, describing the movement of the construction industry in the UK towards an automated digital environment (Stride, Suresh and Renukappa, 2020; Lepore, Micozzi and Francesca, 2021; The University of Cambridge, 2020; Melluso et al., 2020).

\subsection{Negative impact}

The negative impacts of COVID-19 on the construction industry largely stem from the UK Governments 'Construction 2025 report', two-thirds of construction contracting firms are not innovative and consequently freezing technological progress within the sector. Companies experiencing site delays and considerable cash flow issue, skill shortage. Remote working with home-schooling for staff with children was a serious challenge (Stride, Suresh and Renukappa, 2020; Arup, 2020). Alsharef et al., (2021) also noted the challenges experienced from this pandemic as permitting delays, material delivery delays, lower productivity rates, shortage of materials, potential conflicts and disputes, cash flow-related challenges, price escalations and project suspension. Ogunnusi et al., (2020) considered the negative side of COVID-19 as delays in the completion of projects, hardship encountered by daily paid labourers, budget delays, properly scheduled project disruption, real estate sector revenue slowdown (PWC, 2020). Increase rate of mental health issues due to people not having physical contact, especially those who are not used to working from home (King \& Lamontagne, 2021; Stride, Suresh and Renukappa, 2020). Considering the dearth of literature providing details on the positive and negative impact of COVID-19 on the construction industry, this study will conduct an exploratory study on the global impact of COVID-19 on the construction industry.

\subsection{Research gap}

The research gap derived from the review of focal literature in this study, is the lack of considerable article on the impact of COVID-19 on other construction industries outside the scope of the UK, United States, and European Union countries which represent the sources of references in the review of focal literature. Furthermore, there is a lack of information on lessons learned for managing future crisis in the construction industry. This investigation will bridge this gap by studying the perception and influence the COVID-19 pandemic have made in Africa, Asia, and Australia continents to document implications for construction practice and academia. Although Ogunnusi et al. (2020) conducted a similar quantitative study on a global scale, this investigation delves into the lives of the respondents from a qualitative outlook. Additionally, this study is furtherance of Ogunnusi et al. (2020)'s quantitative findings, in this regard a qualitative study.

\section{Methods and materials}

Flick (2009) and De Vaus (2013) identified the mutual features of the quantitative and qualitative interview in the survey strategy. In exploratory studies where the nature of the knowledge is unknown in a social phenomenon, the interpretivist epistemological stand can form a foundational basis for gaining more knowledge about new trends. In this regard, survey interviews were employed in inducing new theories surrounding the impact of COVID-19 on the global construction industry. The structured interview questions were 
designed to extract information from the wider construction industry through the random sampling technique. The random sampling technique provides an unbiased representation of the total population (Cornish, 2007). The nature of the questions asked during the structured data collection which was shared on construction forums and professional social networks such as Linkedln have centred around:

- Lesson learned from this disruption because of COVID-19 on the construction industry.

- The negative impacts of COVID-19 on the construction industry.

- The positive impacts of COVID-19 on the construction industry.

- Benefit from government intervention.

- Unique lessons learned from the pandemic situation

Suggestions on how the construction business or industry should respond to such a pandemic now or in the future. In total, seventy-six (76) respondents responded to the online open-ended structured questionnaire. The anonymity in the process of collecting the data ensured that responses were collected without interfering with the context of the textual data. An Al analytic tool, Zoho analytics was used to analyse the responses and present the data as shown in the next sections. Zoho Analytics is data visualisation for quantitative and qualitative data. This form of qualitative analytics was chosen over NVivo because of the depth of analysis it provides using Al.

The first step in using the Zoho Al analytics tool began with the sorting of the qualitative data in a spreadsheet format. Responses from the 76 respondents were reviewed for similar content, errors and a new spreadsheet summarising the key comments along with the respondents' details and questions were created. The spreadsheet was imported into Zoho analytics were the dashboard for creating common contents in a graphical and visual representation were automatically developed. The visualisation dashboard explored the geographical location of each data in terms of continents, the years of experience of each respondent and their educational qualifications. The final content analysis was categorised according to the years of experience, profession, and geographical location. Thus, there was a reduction of the content in the final visualisation based on cluster mapping of responses. In presenting the outcome of the analyses, the sections below cover the participant profiles and results showing the positive, negative and lessons derived from the COVID-19 pandemic around the world.

\subsection{Participant profile}

Figure 2 illustrates the 76 participants around the world, which were distributed across five (5) continents excluding South America. Due to the cross-sectional nature of the study, it was difficult to extract responses from South America. However, two (2) responses were received from North America, thirteen (13) from Europe, sixteen (16) from Asia, forty-four (44) from Africa, and one (1) from Australia. The range of years of experience in this study are < 5 years; 5-10 years; $11-15$ years and over 15 years. The location and years of experiences were used in the Zoho analytics platform to filter interviewee comments bothering around the ideas of positive impact, negative impact and lessons learned. A breakdown of each participants' professiona, country of residence, years of experience and specialiations can be found in Appendix A. 
$>>$ Insert Figure $2<<<$

$>>$ Insert Figure $3<<<$

$\gg>$ Insert Figure $4<<<$

Figure 3 displays the breakdown distribution of the participants along the professional lines. Figure 3 presents the professional codes for Civil/Structural Engineering; Construction Project Management; Quantity Surveying; Architecture; Building Engineering; Electrical Engineering; and Mechanical Engineering. Africa has all the distribution of professionals in the investigation, followed by Asia (Quantity Surveying and Construction Project Management) and Europe (Building Engineering; Quantity Surveying; Construction Project Management; Civil/Structural Engineering; and Electrical Engineering).

Figure 4 indicates the academic qualification of the respondents. $60.5 \%$ of the participants hold Master of Science (MSc) degrees, 31.6\% have first degrees, $7.5 \%$ have a higher education or college degree and the remaining population, $0.4 \%$ have Ph.Ds. The educational qualification is essential in understanding the nature and quality of responses.

$>>$ Insert Figure $5<<<$

The roles of the individual professionals involved in this study, as shown in Figure 5, further indicates the diversity of the participants in this study. The architects (ARC) involved in this study mainly act as contractors (1) and designers (11). The building engineers (BE) are work as development authority on behalf of the client (1) and designers (2). Construction project managers (CPM) work on behalf of the client (4), act as designers or consultants (10) and contractors (13). Civil/structural engineers (CSE) respondents have 1 interviewee working as a development authority, 3 CSE act as clients, 6 of them are contractors and 7 are designers or consultants who work for clients. Only 1 electrical engineer in this study work as designers or consultants. The single mechanical engineer (ME) in this study is a designer. The quantity surveyors (QS) have one who acts in the role of a client and 7 QSs work on behalf of the contractor.

\section{Qualitative analysis and discussion of findings}

The analysis was of the responses in terms of the positive, and negative impacts along with lessons learned through Zoho Al analytics web-based platform. The respondents' professions and years of experience were mainly used to outline the key responses. The content analysis of the findings necessitated the convergence of similar responses generated from the professional and years of experience viewpoints were collated and compiled in Tables to further strengthen the discussion of the merging themes. The discussion of each theme was supported with literature and the implications of the findings on the future of the construction industry were considered subsequently.

\subsection{The positive impacts of the COVID-19 Pandemic on the construction industry}

From the qualitative analysis as presented in Figure 6 and Table 2, the positive impact of COVID-19 on the construction industry were derived from the respondents based on their 
years of experience. Based on the legend as illustrated in Figure 6 , a broad range of clustered responses were derived across the five (5) continents involved in the study. A larger proportion of the cluster came from respondents with over 15 years of experience, and they are mainly from Africa as indicated by the larger blue circle. There were fewer and non-applicable responses from Asia (in purple).

\section{$\gg>>$ Insert Figure $6<<<$}

$\gg>$ Insert Table $2<<<$

Table 2 presents the themes which emerged from combining the common contents, responses from Figure 6 and the cluster graph in Appendix B. In the next subsections, the six (6) themes identified in Table 2 will be discussed.

\subsubsection{Overhead cost reduction}

Overhead costs are the hidden cost of production which forms of company production managerial indirect cost (Chan, 2012; Liu et al., 2019; Omotayo \& Kulatunga, 2017). Interviewee CSE4 from Nigeria, stated that "there have been improved financial control and management during the pandemic". Construction company overhead cost reduction is a major highlight of the positive imapcts of COVID-19 pandemic on construction businesses. Overhead costs may result from the cost of insurance, administrative charges related to payments, cost of electricity and water supply just to mention a few. In the COVID-19 pandemic, construction overheads such as the cost of travelling to construction sites and office reduced. Transportation cost which may be reimbursed by contractor or construction project managers were saved. Similarly, remote working consider being minor, yet significant costs. These costs may come from printing, stationaries, and other administrative indirect costs. Respondents from Europe, Asia and Africa who are mainly Architects, Quantity Surveyors and Construction project managers identified the cost reduction in their construction businesses as the benefit of the COVID-19 pandemic.

\subsubsection{Remote working environment}

Opportunities to work from home as a new flexible work-from-home model in the construction industry had been identified as a benefit of the construction from the qualitative analysis. CPM6 from the Middle East and North African region, noted that "Increased use of web based technologies for communications and adaptability to more and more remote working". Accessibility to webabsed communication platforms has been a major opportunity for construction professionals to work from home. Stride, Suresh and Renukappa (2020) and Arup (2020) have previously identified remote working as a key benefit that may facilitate the reduction of overhead costs in the construction industry. Pirzadeh and Lingard (2021) studied the impact of remote working on the mental health of construction workers. These scholars discovered that there is a positive relationship between mental well-being and quality of sleep (Pirzadeh and Lingard, 2021). The study conducted by Pirzadeh and Lingard (2021) further discovered that construction workers preferred to work from home. Generally, these findings were supported across the range of participants in the survey. The benefit of remote working in the construction industry can be linked with overhead cost reduction. When employees of the construction industry work from home, all overhead costs associated with office-related activities such as printing, electricity, waste and water usage are eliminated. 


\subsubsection{Crisis management plans}

The common responses and content from the analysis noted that construction organisations now have an idea of how to plan for future crisis. Respondent BE2 from the United Kingdom stated that "appropriate planning and coordination of personal and site activities". Similarly, CSE12 from Nigeria opined that "..it gives clear vision on how business can be planned against unforeseen circumstances". Many construction organisations around the world made use of the COVID-19 epidemic to evaluate their strengths and understood the purpose of resilience and crisis management in charting a new course for their organisation. However, this impact is more significant in short term strategic decision-making in construction organisations around the world. The COVID-19 pandemic has now made construction organisations prepare for the worst-case scenarios; provide a clear vision on how construction businesses can be managed in the instance of another epidemic whilst understanding how to manage businesses in times of crises. Although the Joint Contract Tribunal (JCT) and the New Engineering Contracts 4 (NEC) suites of contract documents do not expressly provide clear provisions for epidemics such as COVID-19, the "force majeure" concept can be interpreted for conditions of contract where construction works will go on in an epidemic.

\subsubsection{Focus on health and safety}

Health and safety measures in construction sites around the world became the centre of attention during the peak of the COVID-19 epidemic. CPM21 from Australia stated that "there is a heightened sense of health and safety in the Australian construction industry...". The pandemic has created more conscious effort to improve construction health and safety measures. Consequently, there is more attention on health and safety measures on construction sites. Furthermore, when construction professionals return to their offices, more health and safety measures such as sanitisation, and personal protective equipment may be provided. Consequently, Alsharef et al. (2021) noted that safety measures such as face masks, social distancing protocols and staggering construction operations have been adopted on construction sites to mitigate the impact of COVID-19. These measures will be in place for many years on construction sites. The focus on health and safety measures findings are from all continents involved in this study.

\subsubsection{Improved productivity}

All the participants in this investigation pointed out several factors indicating improved productivity as a result of remote working in the construction industry. Responded in Africa noted that reduced working hours when working from home did not affect productivity. CPM27 from Nigeria explained that "...eliminated impact of traffic to work on working time and productivity...". The elimination of traffic time created productive time while working from home. This set of respondents also noted that they had more family time, and they were able to rest and prepare better plans concerning their activities. Improved productivity may also result from flexibility in the workplace as noted by African and Australian respondents who were able to return to work at their convenience when the epidemic situation was better. Improved productivity was identified by Pirzadeh and Lingard (2021) as a key benefit of working flexibly in-office setting or at home. This key feature can be linked with sustainable practices in the construction industry.

\subsubsection{Sustainability goals}


As part of the United Nations (UN) sustainable development goals 11, 12 and 13 (United Nations, 2015), which considers sustainable cities and communities; responsible consumption and production; and climate actions can be met with less carbon emission, travel, and less paperwork. Remote work has reduced carbon emission from cars in traffic, water, and electricity usage in offices. CMP27 from Nigeria also linked the time spent on traffic with carbon emission reduction. Furthermore, waste generated from homes is collected from central locations as opposed to waste which would have been generated from offices and homes. Hence, carbon emission from waste disposal from offices would be lower during COVID-19. Studies conducted by Aldaco et al. (2020); and Klemeš et al. (2020) identified a drastic decrease in carbon emission, food? and plastic waste during the peaks of COVID-19. Thus, from a positive perspective COVID-19 is beneficial for attaining the UN susttainable goals. However, the negative impacts on the mental well-being of workers in construction, and the deaths resulting from COVID-19 makes this epidemic a negative influence on the construction industry.

The abovementioned themes highlighting the positive impacts of COVID-19 on the construction industry does not discount the existence of the negatives and should only be viewed as an opportunity to learn from the negative influence of COVID-19 on the construction industry.

\subsection{The negative impact of the COVID-19 Pandemic on the construction industry}

Following the consistent pattern of categorising the comments of the respondents in this study, themes were developed from Figure 7 cluster maps. From the cluster map in Figure 7, most of the participants in Europe and Africa provided key comments on the negative impact of COVID-19 on their finances; businesses; projects and mental health while working from home; project delivery and their ability to keep on working in the face of negativity.

The outcomes of this analysis as illustrated in Figure 7 shows that a larger proportion of the comments came from professionals with over 15 years of experience in the construction industry. This category of respondents were all from around the 5 continents in this study.

\section{$\gg>$ Insert Figure $7<<<$ \\ $>>>$ Insert Table $3<<<$}

Respondents with 5-10 years of experience in this section of the study were mainly drawn from Europe, Africa, and Asia. The least number of responses and clusters came from respondents with less than 5 years of experience. Furthermore, the cluster analysis from Figure 7 led to the theme development in Table 3. Four (4) main themes were developed from the cluster graphs of Figure 7 and Appendix C. They are lower business turnover; delays in construction payment and output; difficulties in working from home; and job losses. Each of these themes will be explained in the next subsection.

\subsubsection{Low business turnover}

Participant CSE12 from Nigeria highlighted the negative effect of COVID-19 on construction businesses as being access to capital to mitigate delays in construction activities; lowincome generation from lower construction outputs; revenue loss; increased cost of construction resulting from delays; financial impacts on construction businesses resulting 
fromdisruptions; delayed financial commitments from clients and in some scenarios, clients had to pause their financial outflow to contractors. These negative impacts were also echoed by other participants in this study. Stride, Suresh and Renukappa (2020) and Arup (2020) cited incidents of cash flow issues whilst Alsharef et al. (2021) noted that there were delays and construction material price escalations. Construction businesses just like every other business around the world had to absorb the financial shock of delays in delivering construction materials; downtimes on construction sites; and suspension in cash flow from the client. On construction projects, the contractor depends on the financial flow from the client and lending organisations. In instances where clients have financial constraints, they may consider suspending the project for some few. However, this depends on the conditions of the contract. This theme can be associated with the next theme on delays in construction payments.

\subsubsection{Delays in construction payment and output}

During the peak periods of COVID-19, the respondents cited delays in decision-making on the path of clients. Thereby leading to time loss and late payment. Interviewee CPM25, CSE4 and CSE1 from Nigeria, the United Kingdom, respectively identified delays in payementThe relevant matters clause of JCT contracts does not expressly consider pandemics as incidents requiring compensation for loss and expense. Therefore, the COVID19 epidemic was subject to interpretations by clients and contractors. Alsharef et al. (2021) noted that permitted delays and project suspension were common during the height of the pandemic. Where there are permitted delays, the contractor will be entitled to compensation for losses and expenses. Consequently, construction output declined during the pandemic because the global construction industry experienced a shortage of construction materials, and material delivery delays (Alsharef et al., 2021). The global construction industry also experienced job losses as expressed in the

\subsubsection{Job losses}

Participants from Africa, Europe and Asia noted that there were job losses and salary cuts in the construction industry. Some of the respondents in Africa and Europe also expressed their inability to find new jobs in the construction industry as a major individual setback during the COVID-19 pandemic. BE1 from the United Kingdom identified "...Distrupted socialisation, job loss and redundancy...", as the major negative impacts COVID-19 had on the construction industry. Ogunnusi et al. (2020) and PWC (2020) observed that many labourers encountered financial hardship during the COVID-19. Although governments of developed countries like the United Kingdom and the United States supported businesses with furlough schemes and disaster finance, individually. In many developing countries did not provide such financial opportunities. In the United Kingdom, there was a decline of 83,000 in construction jobs by the second quarter of the year 2020 (Construction News, 2020). Accordingly, many unskilled and semi-skilled construction labourers around the world experienced financial hardship during COVID-19.

\subsubsection{Difficulties in working from home}

As opposed to the improved productivity theme as part of the positive impacts of COVID-19 on the construction industry, some respondents in Africa, Asia and Europe noted that they had space constraints at home. Other respondents noted that they had difficulties in focusing on their work whilst working from home because of their children as opined by 
respondents CPM8 from the UAE and ARC3 from Nigeria. Additional daily tasks of house chores and taking care of children were also identified as factors stifling their productivity. Stride, Suresh and Renukappa (2020); and King and Lamontagne (2021) discussed the impact of working from home and mental health challenges faced by construction professionals. Some construction professionals only focused on their work and had no social interaction with their colleagues. The challenges of working from home and mental health are evident in the fact that some construction professional may decide to work when they should be sleeping.

The negative impacts of COVID-19 on the construction industry must lead to new lessons for the advanced construction businesses; project delivery and management; the supply chain; health and safety; and new working environments.

\subsection{Lessons learned for future-proofing the construction industry}

The responses on lessons learned were mainly from Europe and Africa. Few responses were extracted from North America and Asia. Respondents with over 15 years of experience provided more of the clustered lessons learned from COVID-19. Participants with 11-15 years and 6-10 years of experience also contributed to the cluster of responses as indicated in Figure 8.

$>>>$ Insert Figure $8<<<$

>> Insert Table $4<<<$

The construction of the themes in Table 4 combined comments from clusters in Figure 8 and Appendix D. The lessons learned are themed as supply chain management; construction project management; health and safety concerns; and virtual working environments. The themes are similar to the positive and negative impacts of COVID-19 on the construction industry. However, in the context of this subsection, the lessons derived from these positive and negative impacts for the future of the construction industry will be discussed.

\subsubsection{Supply chain management}

The construction supply chain is sacrosanct to construction project delivery. In the advent of the COVID-19 pandemic, the supply chain was hampered by the constraints of customs delays and safety standard in the form of cross-border in delivering construction materials. Consequently, the respondents in the study identified the lessons of early procurement and proforma invoicing. Proforma invoicing is a preliminary bill of sale sent to buyers by the suppliers in anticipation of the delivery of construction materials. The proforma invoicing should not be confused with payments for the delivery but a confirmation of the quantities and date of delivery. In this regard, early issuance of proforma invoicing may facilitate the delivery of construction materials. Interviewee CSE10 from Nigeria opined that "Integrate technology in supply chain is important, as this is one of the most impacted areas". CSE10 was suggesting an opportunity to enhance the supply chain system of Nigeria with new technology such as BIM. The application of an integrated supply chain along with building information modelling, the format of the 4D BIM supply chain (Magill et al., 2020), is another way of improving the supply chain. 4D BIM integration with the supply chain will provide a single-point holistic approach to effective enagement with suppliers. This 
considers the nature of decentralised supply chain system with the construction industry and its importance to project success. Therefore, the construction industry must not continue to view the supply chain as it was in the post-COVID-era.

\subsubsection{Improving construction project management}

All the respondents in this study agreed that there should be more focus on construction planning and management. The idea of having the best plan to protect projects from disruptions seems to be a fallacy in the wake of the COVID-19 epidemic. Consequently, the respondents believe that well-planned projects can be disrupted. CSE6 from Nigeria suggested that "well planned construction project management can be disrupted by natural events". Hence the need to improve construction crisis and risk management responses in project plans. The future is unpredictable and there should be more contract administration planning for better interpretation of force majeure. The idea of proactive planning was suggested by the respondents. Proactive planning involves building more flexible construction teams who will be resilient to change and crisis. Hence, construction crisis management must be more relevant in managing construction processes. Improving construction processes by adopting modern methods of construction such as blockchain technology; offsite manufacturing; 3D printing; mobile project management; $\mathrm{Al}$ in the construction industry; and BIM are major technologies that will be very effective in cushioning the effect of the epidemic on construction processes and delivery.

\subsubsection{Focus on occupational health and safety}

One of the major lessons learned from the construction industry is the lack of personal protective equipment (PPE), not only in developing continents such as Africa and Asia but in Europe North America and Australia. CPM12 from Canada suggested that "health and safety has now become more important in the construction industry". PPE equipment range from eye, head, feet, nose, hand, and arm protective equipment. The need for extra protective equipment for nose protection was immediately felt during the pandemic. Consequently, the idea of social distancing on construction sites seems not feasible in many continents involved in this study. From a different viewpoint, social distancing on construction sites necessitated patience and fewer on-site workers. This implied that construction workers will have to rotate their shift during the hours of the day, and this may contribute to their mental well-being. In general, the construction industry now understands the need to focus on safety in the construction industry in a post-COVID era. Felipe et al. (2017) opined that there should be a focus on the mental health of construction workers, especially migrant workers. The challenge of social isolation during COVID-19 may persist in the post-COVID-19 era. More attention should also be given to the nature of safety measures in place on construction sites. At the moment, there is no viable study to show COVID-19 transmission rates on construction sites. However, the construction industry should place more emphasis on protecting construction workers on-site the same way office-based construction professionals are protected.

\subsubsection{Virtual working environments}

Office-based construction workers seem to be more protected in terms of health and safety consideration when compared with on-site based construction workers. Respondents such as CPM14, ARC3, EE1, BE1, QS1 and CSE2 in the 5 continents noted that virtual working environments have been very effective in construction collaboration; workspace 
management; working from home and it facilitated convince in making sure people work flexibly and more productively. On the contrary, King and Lamontagne (2021) argued that working from home may lead to more social isolation and mental health issues. The lesson learned from the virtual working environment is that construction organisations need to devise new means for monitoring workers at home. A recommended limit of working hours can be designed for virtual environments because it is likely construction professionals may want to finish a weeks' work in a day. Large construction organisations may also invest in the virtual working environment for privacy and online safety.

\section{Implications of findings: future-proofing the construction industry.}

The ability to continue to provide the programmes of work that are needed to reinforce the world's economic growth and recovery shortly requires that the consultants, clients and contractors come together and proffer a common solution to the challenges encountered during the pandemic (Mace, 2020). From six projects studied by Loughborough University (2020), working practices and site layouts have seen considerable changes in a brief space of time with the changes being considered successful and well-received. Other lessons learned for the future of the construction industry were aimed at improving the management of COVID -19 risk at work; improved supply chain relationships and responsibility; workers engagement; efficient site induction processes; increase in remote meetings using communication technologies. It was also learned that the adaptive ability of the construction industry to the challenges posed by COVID 19 has demonstrated its resilience, flexibility to provide solutions to problems, enabling quite a lot of projects to proceed with quick onboarding innovations which would normally have taken numerous years to implement. It is however recommended that construction companies conduct lessons learned reviews to maintain the positive changes experienced during the pandemic.

For ultimate safety and health reasons, construction sites were categorised as essential and non-essential with the latter closed by the New York Governor (Robbins, 2020). Page (2020) also categorically states that "force majeure" is not the best solution. This may depend on the contract content whether it is with or without relief provisions. Further developments of standard contract suites such as the JCT should provide inclusions for epidemics such as COVID-19 and how contracting parties should act in such circumstance. Improved collaboration is essential, as construction contract solely are unlikely to provide solutions to all outcomes. As project resumes and site reopens, existing contracts may be modified to reflect the "new normal", that is, COVID 19-specific provisions such as Health and Safety, Site Management, Materials and Supplies Shortages, Performance Security and Step-in Rights.

\subsection{Implications for further research}

The qualitative analysis in this study was conducted to provide an opinionated overview of how COVID-19 has impacted the lives of people in the construction industry around the world. The outcomes of the findings also provide more insights into uncovered research topics on how COVID-19 will shape the trajectory of the construction industry. The following headings are areas of future research.

- The effectiveness of modern methods of construction during the COVID-19 epidemic

- The impact of BIM in the COVID-19 epidemic. 
- Improving stakeholder management and collaboration in a post-COVID-19 pandemic era.

- Enhancing standard form of contract suite to meet the needs of epidemics.

- COVID-19 transmission on construction sites.

Considering the enormity of influence COVID-19 have had on the global construction industry, there is a need to further study the impact of COVID-19 on the construction industry. The abovementioned research areas may be studied from a micro-perspective of national, geographical, organisational, project, economic, social and technological inclinations.

\section{Conclusion and limitations of the study}

The positive, negative and lessons learned impacts of COVID-19 on the global construction industry were felt in the areas of the construction supply chain; contract administration; construction project management; changes to the working environment; health and safety management; and the finances of construction organisations and individual employees of the construction industry. Positive impacts of COVID 19 in construction industry were virtual alternatives, lower interest rate while negative impacts were site delays, cash flow issues, skill shortages, project suspensions amongst others. The positive impacts can also be felt in the continuous improvement of industry 4.0 in the UK construction industry. On the other hand, increase in the rate of mental issues due to non-physical contact as a result of unexpected change in working environment (homeworking) is a major negative impact that should be given a significant consideration in the industry.

In this light of these analyses, it has become imperative for built environment research to focus on new strategies and frameworks for future-proofing the construction industry. The application of existing technology and new processes such as BIM; Al; machine learning; teleconferencing for virtual site monitoring of construction sites have become more sacrosanct for the delivery of construction products and services.

This study was conducted with the view of obtaining large scale qualitative findings. In all, 76 respondents provided feedback from 5 continents excluding South America. In so doing, this study's limitation is evident in the lack of responses from South American construction professionals. This was due to the language barrier and accessibility. Notwithstanding, the outcomes of this study provide a broader viewpoint of how COVID-19 affected the construction industry and the implications of the findings. A single respondent from Australia is also a limitation in this study even though it included Australia as a continent. The implications of the lessons learned for construction project management; construction occupational health and safety; supply chain management; and virtual working environments; all necessitate advanced in construction information technology and research.

\section{Appendices}

>>Insert Appendix $A<<<$ 
$\gg>>$ Insert Appendix $B<<<$

$\gg>$ Insert Appendix $\mathrm{C}<<<$

$\gg>>$ Insert Appendix $\mathrm{D}<<<$

\section{References}

Aldaco, R., Hoehn, D., Laso, J., Margallo, M., Ruiz-Salmón, J., Cristobal, J., Kahhat, R., Villanueva-Rey, P., Bala, A., Batlle-Bayer, L., Fullana-i-Palmer, P., Irabien, A., \& VazquezRowe, I. (2020). Food waste management during the COVID-19 outbreak: a holistic climate, economic and nutritional approach. Science of The Total Environment, 742, 140524. https://doi.org/https://doi.org/10.1016/j.scitotenv.2020.140524

Alsharef, A. Banerjee, S. Uddin, S.M.J. Albert, A. Jaselskis, E. (2021). Early Impacts of the COVID-19 Pandemic on the United States Construction Industry. International Journal of Environmental Research and Public Health, 18, 1-20.

Arup. (2020). Mitigating COVID-19 risks during construction.

Babu, S. S. and Sudhakar, B. (2016). Construction Project Management during Economic Crisis. International Journal of Scientific \& Engineering Research, 7(12), 625-633.

Chan, C. T. W. (2012). The principal factors affecting construction project overhead expenses: An exploratory factor analysis approach. Construction Management and Economics, 30(10), 903-914. https://doi.org/10.1080/01446193.2012.717706

Felipe, C. M., Roldán, J. L., \& Leal-Rodríguez, A. L. (2017). Impact of organizational culture values on organizational agility. Sustainability (Switzerland), 9(12). https://doi.org/10.3390/su9122354

FinancialNigeria. (2020). Nigeria's Construction Industry to contract by $12.8 \%$ in 2020.

Jones, W., Chow, V., \& Gibb, A. (2020). Covid-19 and construction: Early lessons for a new normal? Lougborough University, August, 1-18.

King, T. L., \& Lamontagne, A. D. (2021). COVID-19 and suicide risk in the construction sector: preparing for a perfect storm. Scandinavian Journal of Public Health, January, 1-5. https://doi.org/10.1177/1403494821993707

Klemeš, J. J., Fan, Y. Van, Tan, R. R., \& Jiang, P. (2020). Minimising the present and future plastic waste, energy and environmental footprints related to COVID-19. Renewable $\begin{array}{llll}\text { and Sustainable Energy Reviews, } 127, & 109883 .\end{array}$ https://doi.org/https://doi.org/10.1016/j.rser.2020.109883

Kshirsagar, A., Mansour, t., Metakis, M. (2020). Adapting workplace learning in the time of coronavirus. McKinsey.

Lepore, D., Micozzi, A., \& Spigarelli, F. (2021). Industry 4.0 accelerating sustainable manufacturing in the covid-19 era: Assessing the readiness and responsiveness of italian regions. Sustainability (Switzerland), 13(5), 1-19. https://doi.org/10.3390/su13052670

Liu, S., Wu, J., Yue, Y., \& Zhang, Y. (2019). Analysis of Factors Affecting the Hidden Costs of Construction Projects Factor Analysis. OALib, 06(08), 1-8. https://doi.org/10.4236/oalib.1105665

LoughboroughUniversity. (2020). COVID -19 and Construction: Early lessons for a new normal? 1-18.

Mace. (2020). COVID-19 Insight - Navigating A New World.

Magill, L. J., Jafarifar, N., Watson, A., \& Omotayo, T. (2020). 4D BIM integrated construction supply chain logistics to optimise on-site production. International Journal of 
Construction

Management,

$0(0)$,

$1-10$. https://doi.org/10.1080/15623599.2020.1786623

Melluso, N., Fareri, S., Bonaccorsi, A., Chiarello, F., Coli, E., Fantoni, G., Manfredi, P., Giordano, V., \& Manafi, S. (2020). Lights and shadows of covid-19, technology and industry 4.0. ArXiv.

Ogunnusi, M., Hamma-adama, M., Salman, H., \& Kouider, T. (2020). International Journal of Real Estate Studies INTREST COVID-19 Pandemic: The Effects and Prospects in the. 2, 120-128.

Oladirin, T. O. Ogunsemi, D. R. and Aje, I. O. (2012). Role of Construction Sector In Economic Growth: Empirical Evidence From Nigeria. FUTY Journal of the Environment, 7(1), 5060.

Omotayo, T., \& Kulatunga, U. (2017). a Gemba Kaizen Model Based on BPMN for Small- and Medium-Scale Construction Businesses in Nigeria. Journal of Construction Project Management and Innovation, 7(1), 1760-1778.

Page, P. (2020). Recovering from COVID-19 : Lessons Learnt for the UK Construction Industry. Pirzadeh, P., \& Lingard, H. (2021). Working from Home during the COVID-19 Pandemic: Health and Well-Being of Project-Based Construction Workers. Journal of Construction Engineering and Management, 147(6). https://doi.org/10.1061/(ASCE)co.19437862.0002102

PWC. (2020). Emerging Trends in Real Estate Management. 29.

Raftery, J., Pasadilla, B., Chiang, Y.H. Eddie, C.M. Hui, Tang, B. (2010). Globalisation and Construction Industry Development: Implication of Recent Development In The Construction Sector In Asia. Construction Management and Economics, 16.

Rangelova, F. (2015). Fundamentals of Economics In Sustainable Construction.

Rhodes, C. (2019). Construction Industry : Statistics and Policy.

Robbins, J. (2020). Harsh Lessons from Asia: Planning for US recovery.

Schober, K. (2020). What The New Normal Could look Like In Construction.

Stasiak-Betlejewska, R., Potkany, M. (2015). Construction Costs Analysis and Its Importance To The Economy. ScienceDirect, 34.

Stride, M. Suresh, S. Renukappa, S. (2020). The Impact of COVID-19 on the UK Construction Industry.

TheUniversityofCambridge. (2020). The role of industrial digitalisation in post-Covid-19 manufacturing recovery, diversification and resilience. 1-18.

Victor, M. Mmusi, M. and Belinda, A. (2020). Crisis Management Framework : COVID -19 Crisis Response Checklist.

Wibowo, M., A. (2004). Identification and characterization of human PDZRN4L gene and mouse Pdzrn4l gene in silico. International Journal of Molecular Medicine, 13(6), 923927. https://doi.org/10.3892/ijmm.13.6.923 


\section{For the first time since the financial crisis 2008, the COVID-19 crisis is about to interrupt a long period of growth in construction markets}

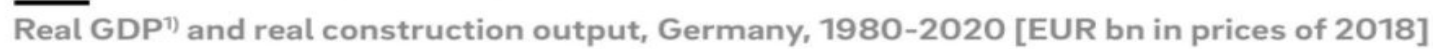

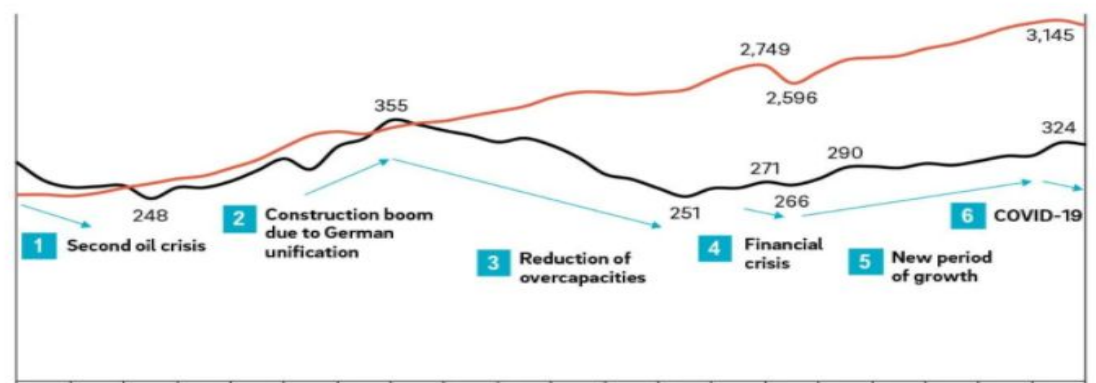

During the last 40 years. periods of a duration of c.1 decade of overatt positive and negative growth have alternated Since 2005, the construction industry is again on a growth trajectory

Last economic crisis before the current the financlated crisis -

the financiat crisis - had

a one time effect as

negative impact could

198019821984198619881990199219941996199820002002200420062008201020122014201620182020

quickly be removed

Figure 1. 1980 - 2020 real GDP and construction output in Germany (Schober, 2020)

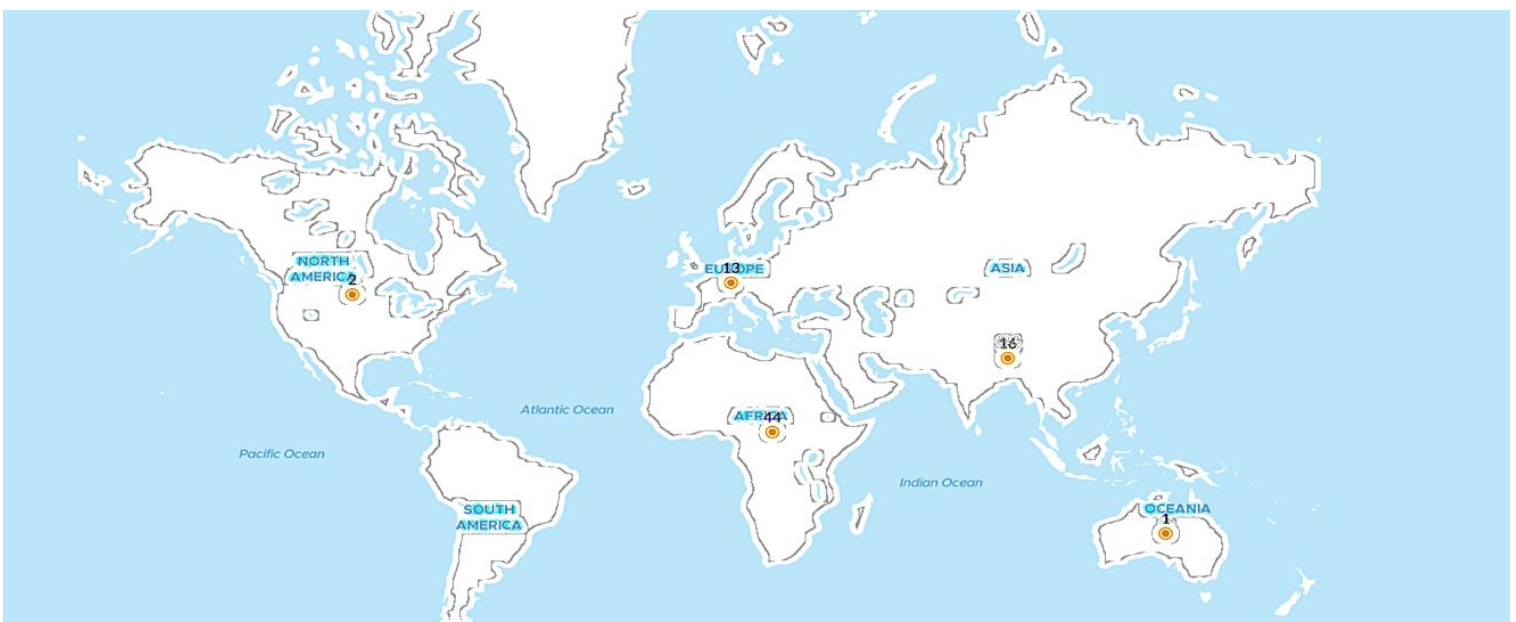

Figure 2. Global distribution of interview data collected from participants around the world

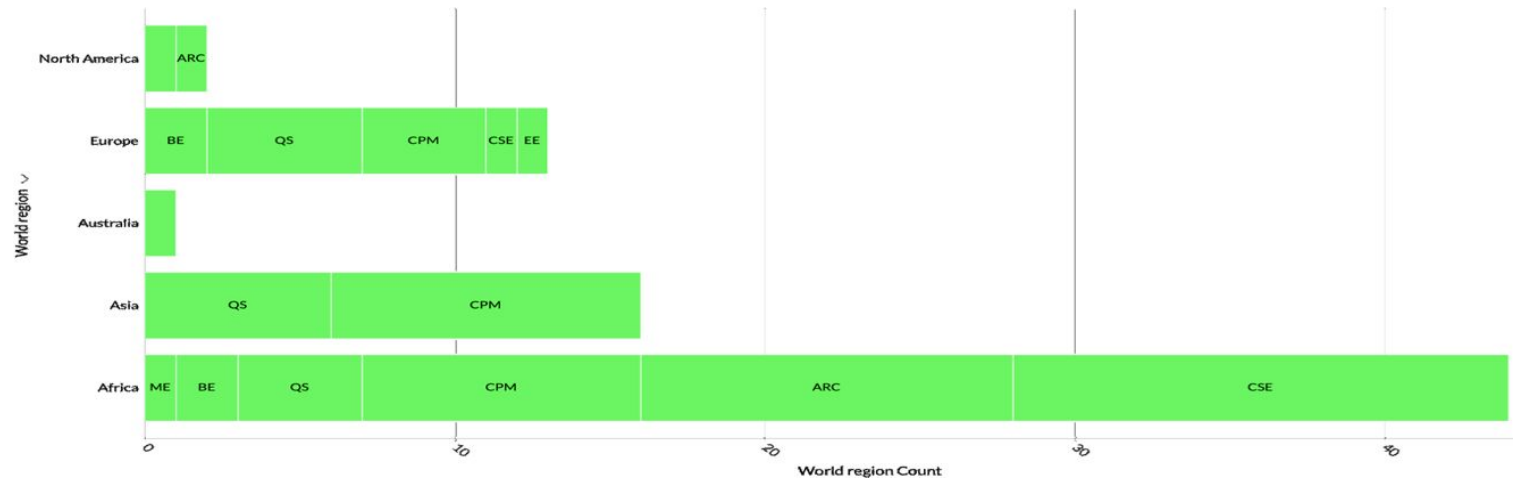

Figure 3. Professional distribution of the participants. 
Professional codes [Civil/Structural Engineering -CSE; Construction/Project Management CPM; Quantity Surveying- QS; Architecture-ARC; Building Engineering- BE; Electrical Engineering- EE; Mechanical Engineering- ME]

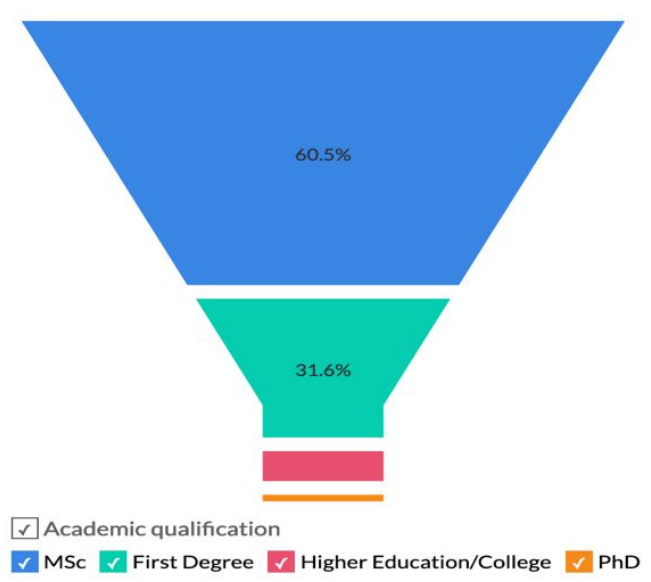

Figure 4. Academic qualification of the respondents.

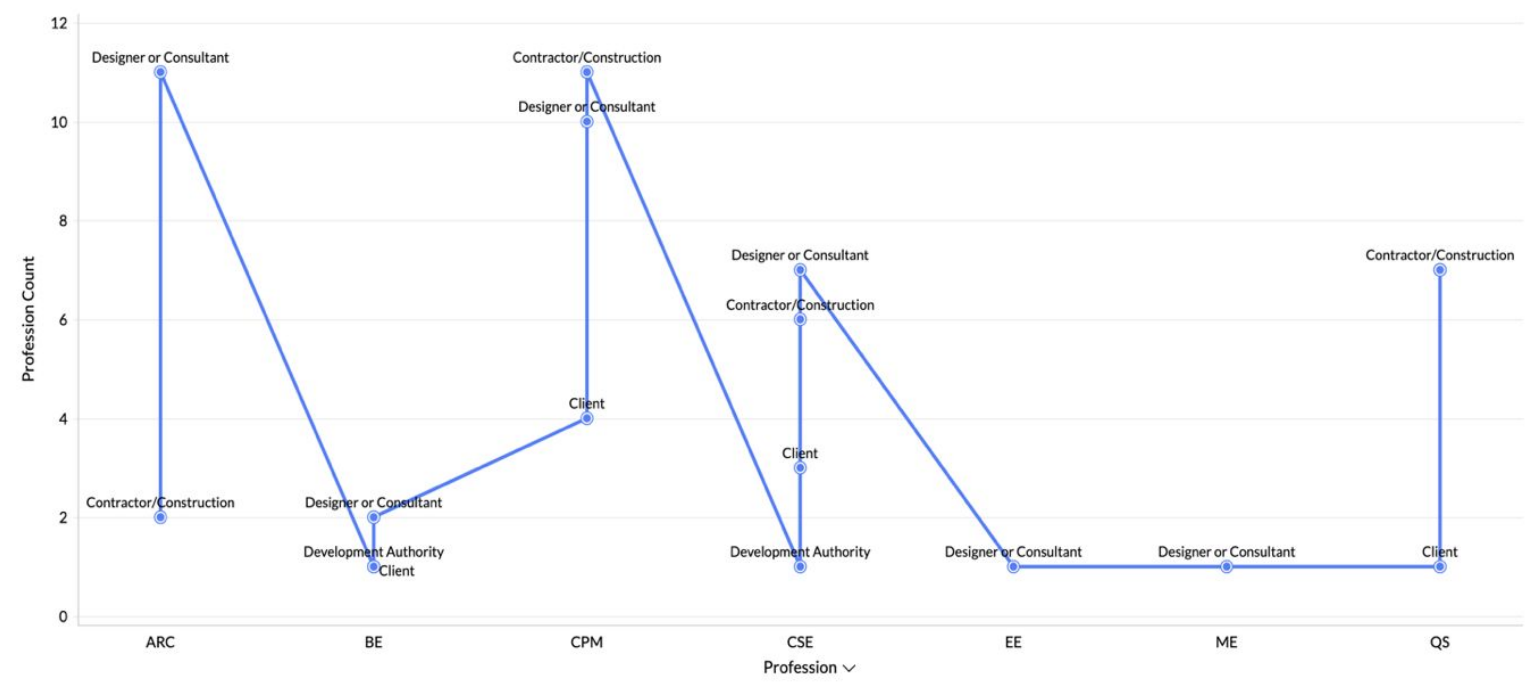

Figure 5. Roles of the various professions in the construction industry. 


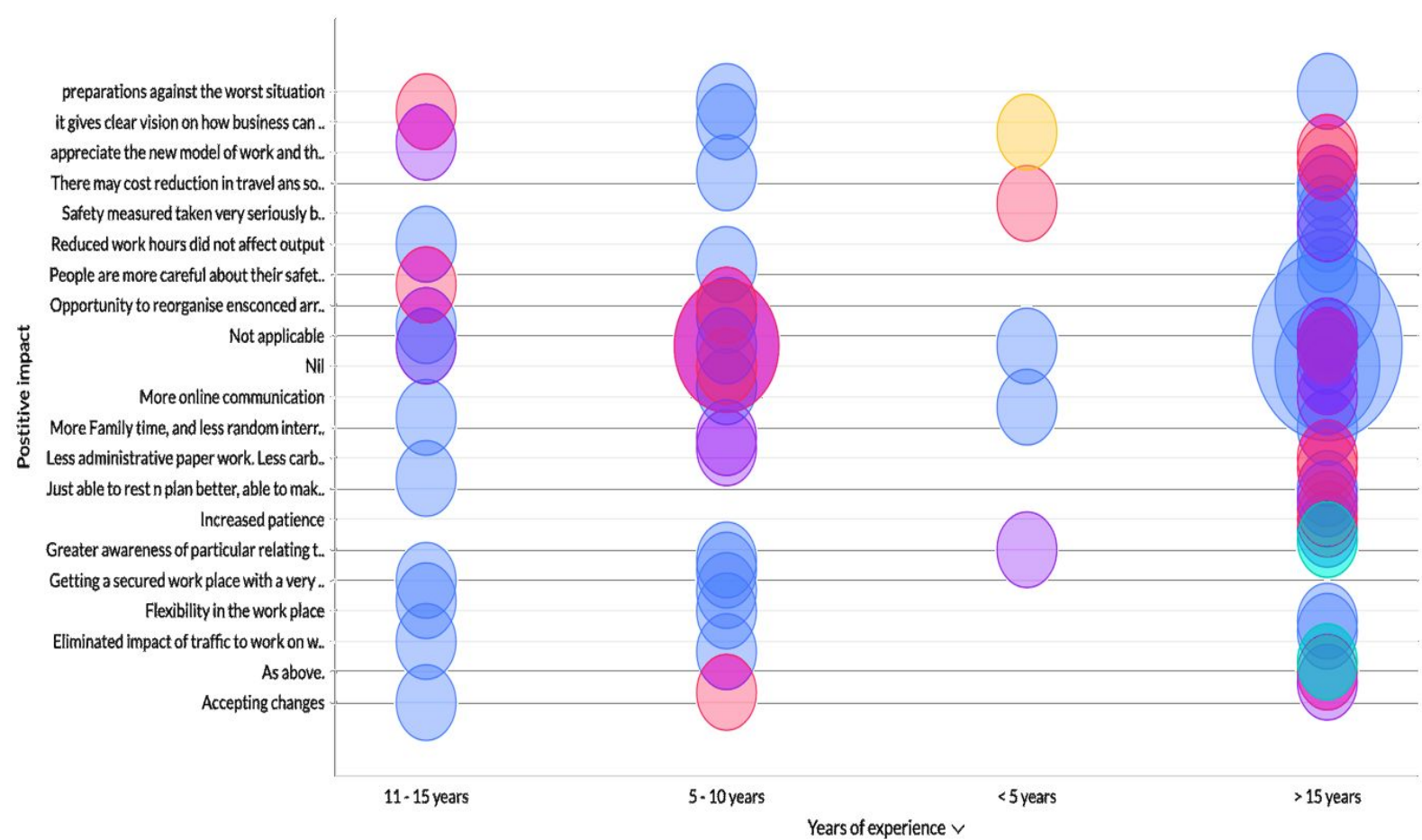

Figure 6. Cluster map showing the positive impact of COVID-19 on the global construction industry

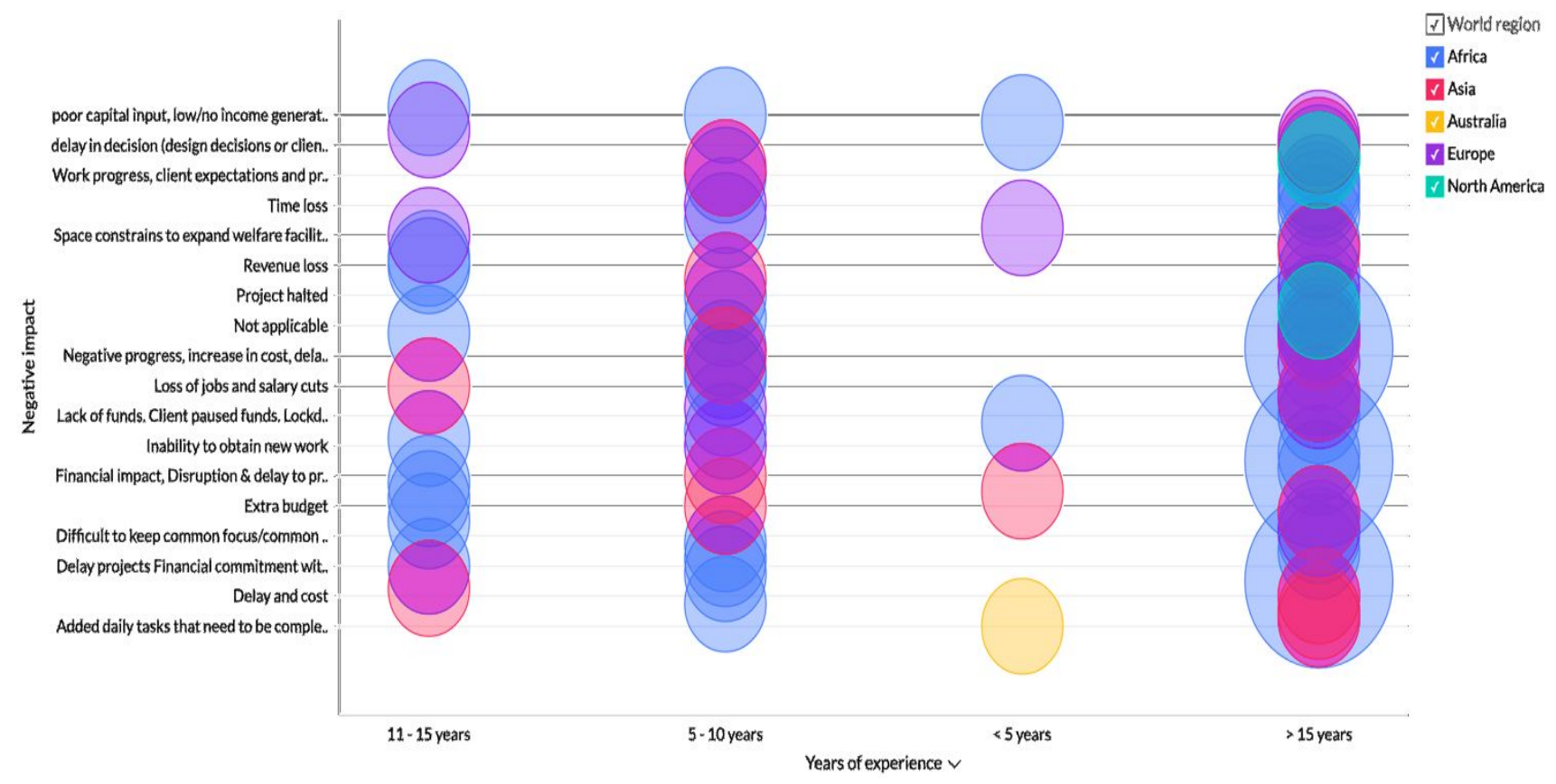

Figure 7. Cluster map showing the negative impacts of COVID-19 on the global construction industry 


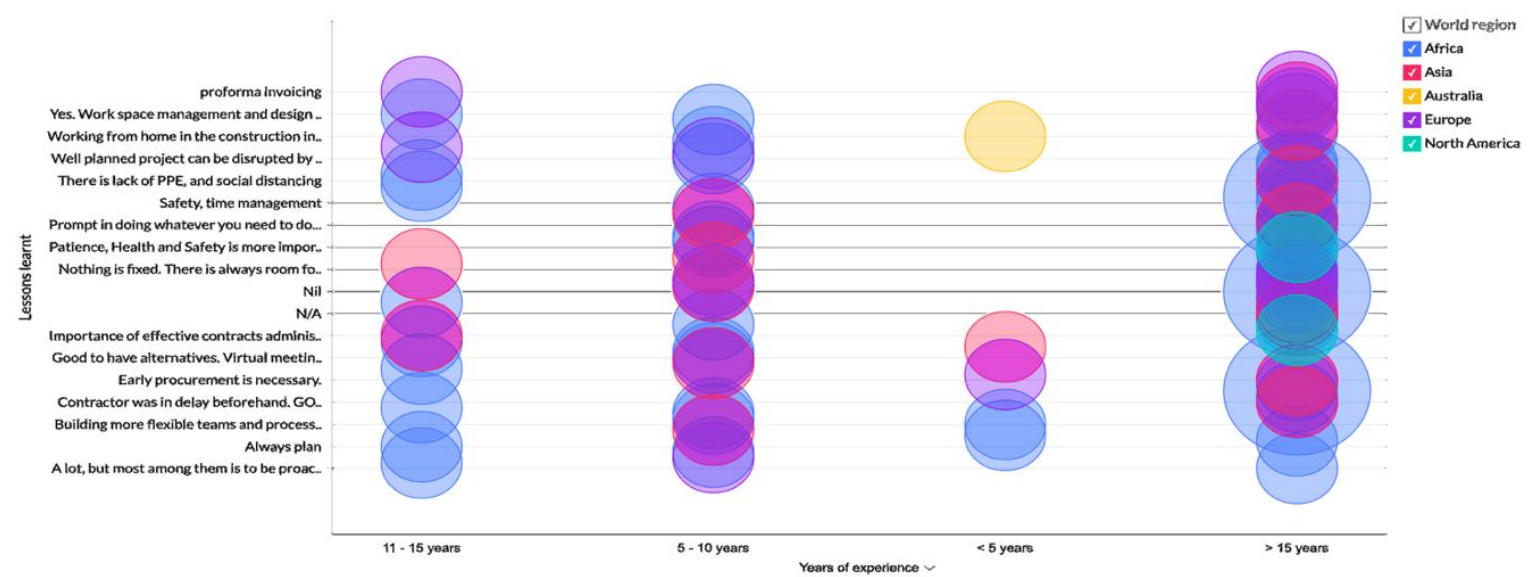

Figure 8. Cluster map showing the lessons learned from COVID-19 on the global construction industry

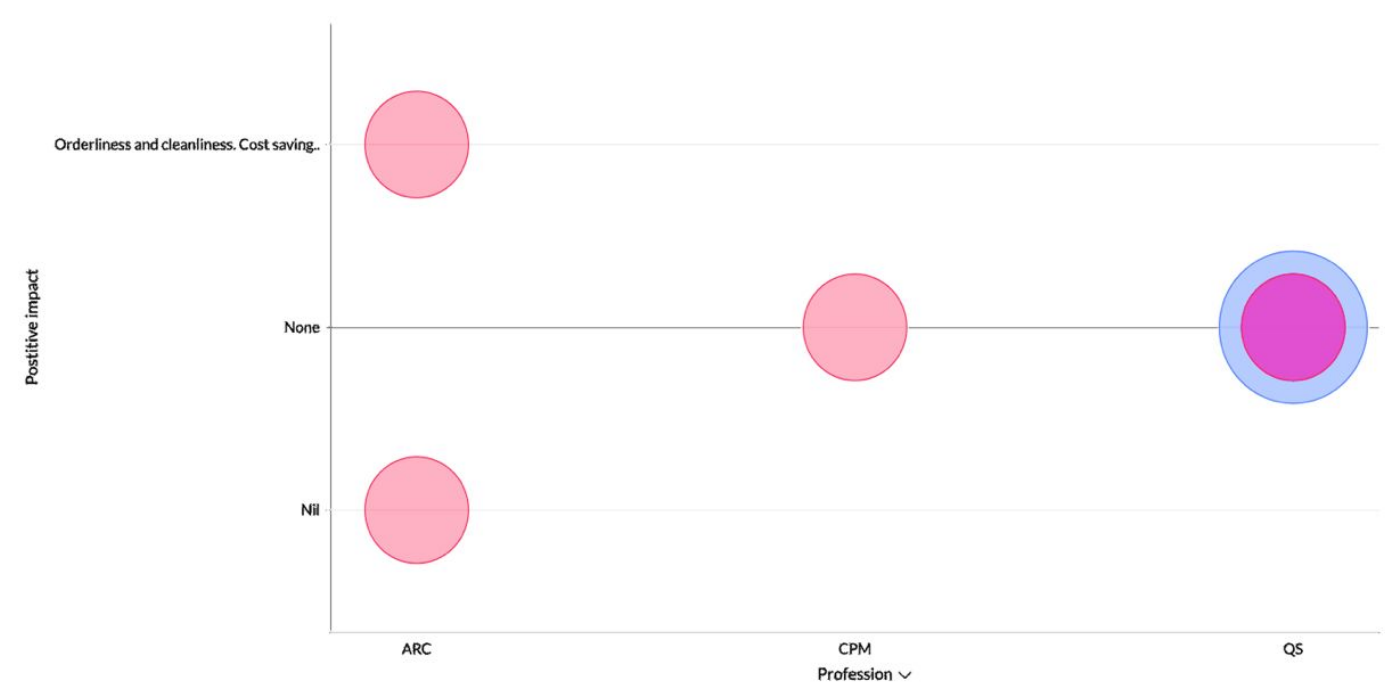

Appendix B. Positive impacts, professional perspectives.

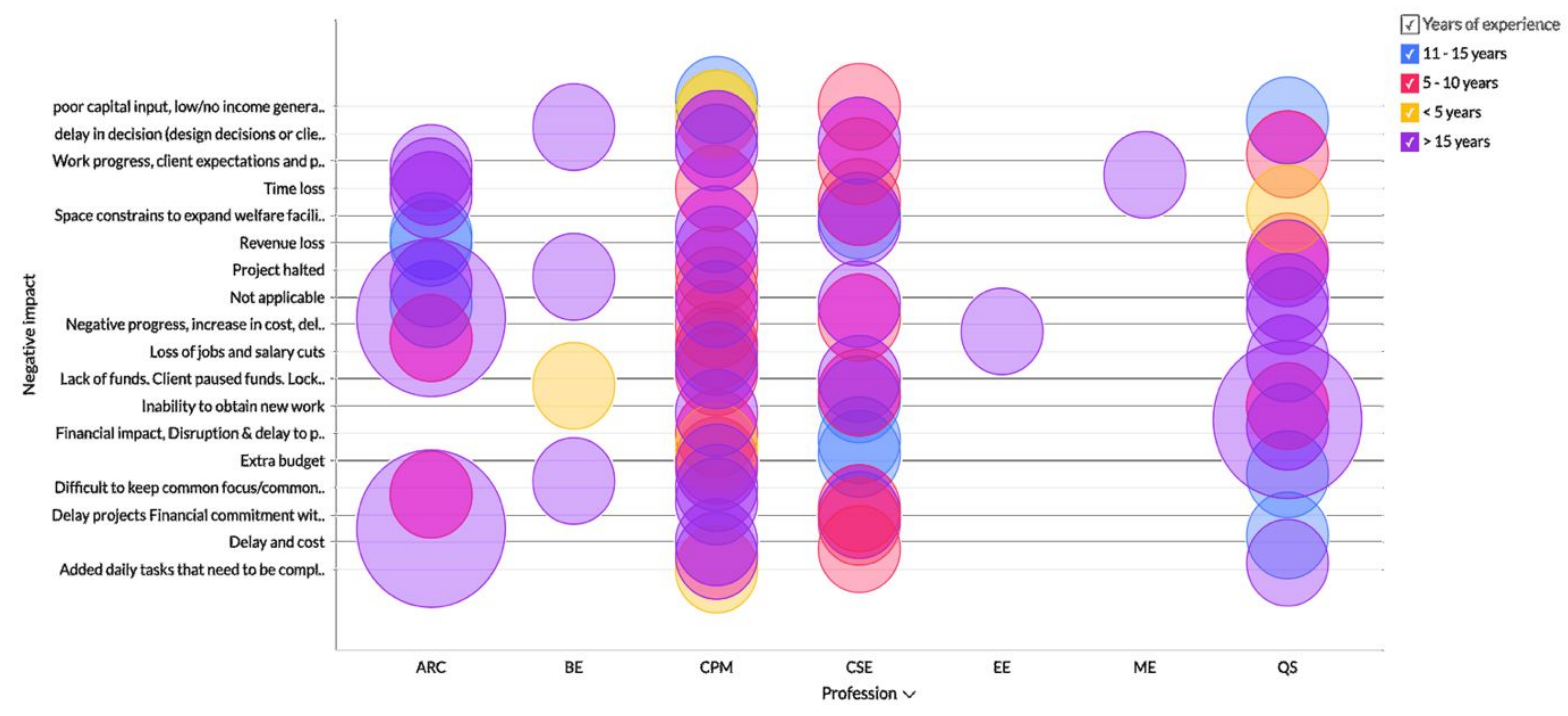

Appendix C. Negative impacts, professional perspectives.

Years of experience

7.10years

Vl> 15 years

团 Years of experience 


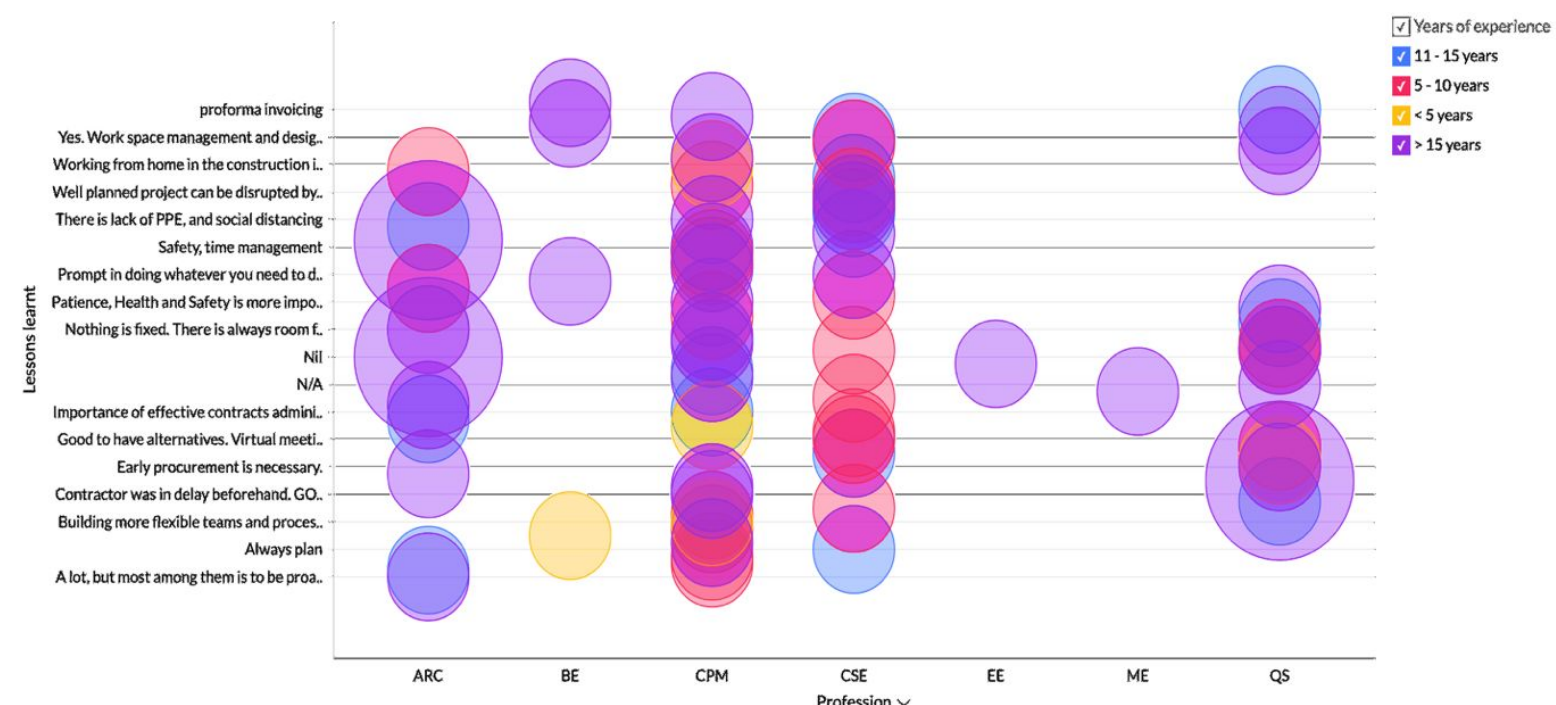

Appendix D. Lessons learned, professional perspectives. 
List of Tables

Table 1. The positive and negative impact of COVID-19 on the construction industry.

\begin{tabular}{|c|c|c|}
\hline $\mathrm{S} / \mathrm{N}$ & Positive impact & Source \\
\hline & Virtual alternatives & [1], [2] \\
\hline & Remote working & [3] \\
\hline & Opportunities to recruit skilled workers & [4] \\
\hline & Lower interest rates & [4] \\
\hline & Higher demand in the residential sector & [4] \\
\hline & Progress of construction industry 4.0 & {$[3],[5],[6],[7]$} \\
\hline & $\begin{array}{l}\text { The more automated digital } \\
\text { environment }\end{array}$ & {$[3],[5],[6],[7]$} \\
\hline & \multicolumn{2}{|l|}{ Negative impacts } \\
\hline & Site delays & [3], [8] \\
\hline & Cashflow issues & [3], [8] \\
\hline & Skill shortage & [3], [8] \\
\hline & $\begin{array}{l}\text { Remote working with home-schooling } \\
\text { for staff with children }\end{array}$ & [3], [8] \\
\hline & Permitting delays & [9] \\
\hline & Material delivery delays & [9] \\
\hline & Lower productivity & [9] \\
\hline & Shortage of construction materials & [9] \\
\hline & Conflicts and disputes & [9] \\
\hline & Price escalations & [9] \\
\hline & Project suspension. & [9] \\
\hline & $\begin{array}{l}\text { Hardship encountered by daily paid } \\
\text { labourers }\end{array}$ & {$[1],[10]$} \\
\hline & Budget preparation delays & {$[1],[10]$} \\
\hline & real estate sector revenue slowdown & {$[1],[10]$} \\
\hline & Increase rate of mental health issues & [3], [11] \\
\hline
\end{tabular}

\{Sources: [1]= Ogunnusi et al., (2020); [2]= Kshirsagar, Mansour and Metakis (2020); [3]= Stride, Suresh and Renukappa (2020); [4]= Alsharef et al., (2021); [5]= Lepore, Micozzi and Francesca, (2021); [6]= The University of Cambridge, (2020); [7]= Melluso et al. (2020); [8]= Arup (2020); [9]= Alsharef et al. (2021); [10]= PWC (2020); [11]= King and Lamontagne (2021)\} 
Table 2. Themes indicating the positive impact of COVID-19 on the global construction industry.

\begin{tabular}{|c|c|c|}
\hline $\mathrm{Nr}$ & Theme & Commonalities \\
\hline & $\begin{array}{l}\text { Overhead cost } \\
\text { reduction }\end{array}$ & $\begin{array}{l}\text { Cost-saving measures; Cost reduction in travelling } \\
\text { arrangement; Opportunity to reorganise ensconced } \\
\text { arrangements, cut back future costs, improved elements of } \\
\text { communications and use of technology e.g. teams }\end{array}$ \\
\hline 2. & $\begin{array}{l}\text { Remote working } \\
\text { environment }\end{array}$ & $\begin{array}{l}\text { Opportunity to improve on virtual alternatives; appreciate } \\
\text { the new model of work and the flexibility provided which } \\
\text { we thought could not be achieved before COVID-19; more } \\
\text { online communication }\end{array}$ \\
\hline 3. & $\begin{array}{l}\text { Crisis management } \\
\text { plans }\end{array}$ & $\begin{array}{l}\text { Preparations against the worst situation; It gives a clear } \\
\text { vision on how business can be planned against unforeseen } \\
\text { circumstances; lessons learnt to be incorporated into future } \\
\text { projects; accepting changes; Greater awareness of } \\
\text { particular relating to force majeure; greater contractual } \\
\text { focus. }\end{array}$ \\
\hline 4. & $\begin{array}{l}\text { Focus on health and } \\
\text { safety }\end{array}$ & $\begin{array}{l}\text { Safety measures took more seriously, Increased patience. } \\
\text { Getting a secured workplace with a very high profile }\end{array}$ \\
\hline 5. & $\begin{array}{l}\text { Improved } \\
\text { productivity }\end{array}$ & $\begin{array}{l}\text { Reduced working hours do not affect output; more family } \\
\text { time; just able to rest and plan better, able to make an } \\
\text { assessment and take a critical decision as it affects the } \\
\text { progress and quality of the project. Flexibility in the } \\
\text { workplace. Eliminated impact of traffic when working from } \\
\text { home. }\end{array}$ \\
\hline 6. & Sustainability goals & $\begin{array}{l}\text { Less administrative paperwork; Less carbon footprint at the } \\
\text { project site; Eliminated impact of traffic when working from } \\
\text { home. }\end{array}$ \\
\hline
\end{tabular}


Table 3. Themes showing the negative impact of COVID-19 on the global construction industry

\begin{tabular}{lll}
\hline $\mathbf{N r}$ & Theme & Commonalities \\
\hline 1. & $\begin{array}{l}\text { Low business } \\
\text { turnover }\end{array}$ & $\begin{array}{l}\text { Poor capital input, low/no income generation, poor } \\
\text { business sustainability; revenue loss; increase in cost; lack of } \\
\text { fund; client paused funds; financial impact and disruptions; } \\
\text { extra budget; delayed project financial commitment. }\end{array}$ \\
\hline 2. & $\begin{array}{l}\text { Delays in } \\
\text { construction payment } \\
\text { and output }\end{array}$ & $\begin{array}{l}\text { delay in decision-making (design decisions or client } \\
\text { decisions); time loss; work in progress; time expectations; } \\
\text { project halted; delay and cost. }\end{array}$ \\
\hline 3. & $\begin{array}{l}\text { Difficulties in working } \\
\text { from home }\end{array}$ & $\begin{array}{l}\text { Space constraints; difficulty in keeping focus; added daily } \\
\text { tasks. }\end{array}$ \\
\hline 4. & Job losses & Loss of job and salary cuts; inability to obtain new work; \\
\hline
\end{tabular}

Table 4. Themes on lessons learned from COVID-19 in the global construction industry

\begin{tabular}{lll}
\hline $\mathbf{N r}$ & Theme & Commonalities \\
\hline 1. & $\begin{array}{l}\text { Supply chain } \\
\text { management }\end{array}$ & Proforma invoicing; early procurement is necessary \\
\hline 2. & $\begin{array}{l}\text { Improving } \\
\text { construction project } \\
\text { management }\end{array}$ & $\begin{array}{l}\text { Well planned projects can be disrupted; time management; } \\
\text { nothing is fixed; Importance of effective contract } \\
\text { administration; contractor's delays; building more flexible } \\
\text { teams and processes; always plan; proactivity. }\end{array}$ \\
\hline 3. & $\begin{array}{l}\text { Focus on } \\
\text { occupational health } \\
\text { and safety }\end{array}$ & $\begin{array}{l}\text { There is a lack of PPE and social distancing; safety, health is } \\
\text { more important; patience; }\end{array}$ \\
\hline 4. & $\begin{array}{l}\text { Virtual working } \\
\text { environments }\end{array}$ & $\begin{array}{l}\text { Good to have alternatives; virtual meeting; Workspace } \\
\text { management; working from home in the construction } \\
\text { industry; prompt in doing whatever you want to do. }\end{array}$ \\
\hline
\end{tabular}


Appendix A. Attributes of the interviewees.

\begin{tabular}{|c|c|c|c|}
\hline NR & Profession & Country & Specialisation \\
\hline 1 & CSE1 & Nigeria & Designer or Consultant \\
\hline 2 & CSE2 & Nigeria & Contractor/Construction \\
\hline 3 & CSE3 & Nigeria & Developer \\
\hline 4 & CSE4 & Nigeria & Contractor/Construction \\
\hline 5 & CSE5 & Nigeria & Contractor/Construction \\
\hline 6 & CPM1 & United Kingdom & Contractor/Construction \\
\hline 7 & CSE6 & Nigeria & Development Authority \\
\hline 8 & CSE7 & Nigeria & Designer or Consultant \\
\hline 9 & CPM2 & Nigeria & Developer \\
\hline 10 & CSE8 & Nigeria & Designer or Consultant \\
\hline 11 & СРM3 & Qatar & Contractor/Construction \\
\hline 12 & CSE9 & Nigeria & Designer or Consultant \\
\hline 13 & QS1 & Saudi Arabia & Developer \\
\hline 14 & CPM4 & Zambia & Contractor/Construction \\
\hline 15 & QS2 & United Arab Emirates & Contractor/Construction \\
\hline 16 & CPM5 & UAE & Designer or Consultant \\
\hline 17 & ARC1 & Barbados & Designer or Consultant \\
\hline 18 & CPM6 & Middle East North Africa Region & Designer or Consultant \\
\hline 19 & CPM7 & South Africa & Contractor/Construction \\
\hline 20 & ARC2 & Nigeria & Designer or Consultant \\
\hline 21 & CPM8 & UAE & Contractor/Construction \\
\hline 22 & ARC3 & Nigeria & Contractor/Construction \\
\hline 23 & CSE10 & Nigeria & Developer \\
\hline 24 & ARC4 & Nigeria & Designer or Consultant \\
\hline 25 & QS3 & Nigeria & Designer or Consultant \\
\hline 26 & ARC5 & Nigeria & Designer or Consultant \\
\hline 27 & BE1 & United Kingdom & Designer or Consultant \\
\hline 28 & QS4 & Nigeria & Designer or Consultant \\
\hline 29 & CSE11 & Nigeria & Designer or Consultant \\
\hline 30 & CSE12 & Nigeria & Designer or Consultant \\
\hline 31 & ARC6 & Nigeria & Designer or Consultant \\
\hline 32 & CPM9 & Nigeria & Designer or Consultant \\
\hline 33 & CPM10 & Nigeria & Designer or Consultant \\
\hline 34 & CPM11 & Nigeria & Designer or Consultant \\
\hline 35 & ARC7 & Nigeria & Designer or Consultant \\
\hline 36 & EE1 & United Kingdom & Designer or Consultant \\
\hline 37 & CPM12 & Canada & Developer \\
\hline
\end{tabular}




\begin{tabular}{|c|c|c|c|}
\hline 38 & CPM13 & United Kingdom & Designer or Consultant \\
\hline 39 & ARC8 & Nigeria & Contractor/Construction \\
\hline 40 & CPM14 & United Kingdom & Developer \\
\hline 41 & QS5 & United Kingdom & Contractor/Construction \\
\hline 42 & CSE13 & Nigeria & Contractor/Construction \\
\hline 43 & BE2 & United Kingdom & Designer or Consultant \\
\hline 44 & CPM15 & Nigeria & Contractor/Construction \\
\hline 45 & ARC9 & Nigeria & Designer or Consultant \\
\hline 46 & BE3 & Nigeria & Developer \\
\hline 47 & ME1 & Nigeria & Designer or Consultant \\
\hline 48 & QS6 & Nigeria & Contractor/Construction \\
\hline 49 & QS7 & Nigeria & Designer or Consultant \\
\hline 50 & CPM16 & Nigeria & Designer or Consultant \\
\hline 51 & QS8 & Oman, Qatar & Contractor/Construction \\
\hline 52 & QS9 & United Kingdom & Designer or Consultant \\
\hline 53 & QS10 & England & Designer or Consultant \\
\hline 54 & CSE14 & Nigeria & Contractor/Construction \\
\hline 55 & CPM17 & UAE & Designer or Consultant \\
\hline 56 & QS11 & UAE & Designer or Consultant \\
\hline 57 & ARC10 & Nigeria & Designer or Consultant \\
\hline 58 & QS11 & Qatar & Designer or Consultant \\
\hline 59 & CPM18 & UAE & Developer \\
\hline 60 & CPM19 & Russia, Middle East and Nigeria & Contractor/Construction \\
\hline 61 & CPM20 & Nepal & Designer or Consultant \\
\hline 62 & CPM21 & Australia & Contractor/Construction \\
\hline 63 & QS12 & United Kingdom & Contractor/Construction \\
\hline 64 & QS13 & Hong Kong & Contractor/Construction \\
\hline 65 & CPM22 & Indonesia & Developer \\
\hline 66 & ARC11 & Nigeria & Designer or Consultant \\
\hline 67 & ARC12 & Nigeria & Designer or Consultant \\
\hline 68 & ARC13 & Nigeria & Designer or Consultant \\
\hline 69 & QS14 & Scotland & Contractor/Construction \\
\hline 70 & CPM23 & India & Contractor/Construction \\
\hline 71 & CPM24 & Ireland & Contractor/Construction \\
\hline 72 & CSE15 & Nigeria & Designer or Consultant \\
\hline 73 & CPM25 & Nigeria & Contractor/Construction \\
\hline 74 & CPM26 & Nigeria & Contractor/Construction \\
\hline 75 & CPM27 & Nigeria & Designer or Consultant \\
\hline 76 & BE4 & United Kingdom & Development Authority \\
\hline
\end{tabular}


[Civil/Structural Engineering -CSE; Construction/Project Management - CPM; Quantity Surveying- QS; Architecture-ARC; Building Engineering- BE; Electrical Engineering- EE; Mechanical Engineering- ME] 